\title{
The effects of eight-week regular training in amateur amputee football team athletes' body composition
}

\author{
Mehmet ILKIM, Burak CANPOLAT, Betül AKYOL
}

Inonu University, Faculty of Sport Sciences Malatya / Turkey.

Address Correspondence to B, Canpolat, e-mail: burak.canpolat@inonu.edu.tr

\begin{abstract}
The purpose of this study is to observe the effects of the 8 week regular training program on body composition of the amateur amputee sports club athletes. 12 amateur amputee athletes in the Malatya Ay Yildiz Amateur Amputee Football Team with ages ranging from 16 to 33 (X age: $24.33 \pm 5.71$ years, $X$ length: $1.74 \pm 8.07$ meters, $X$ weight: $75.09 \pm 15.16 \mathrm{~kg}$ ) voluntarily participated in this study. The training program consists of strength, strength, agility, speed, technique, tactics, coordination and flexibility. Body length, body weight, heart rate measurements, skin fold thickness of three different parts and body mass index (BMI) were measured before and after the 8 week training period to evaluate body composition. Densities were calculated using the Jackson and Pollock (1978) formula, taking into account the skin fold thickness measurements made. Percent body fat is calculated using Siri's formula. The body mass index is determined by the World Health Organization (WHO) formula. A statistically significant difference was found in the comparison of the athletes' weight, resting heart rate, body mass index and body fat percentage in the first and last week measurements according to Wilcoxon signed rank test results $(\mathrm{p}<0.05)$. As a result, in this study; The 8-week training program which includes strength, strength, speed, agility, coordination, technique and flexibility enhancing exercises showed significant changes in parameters of body composition of Ay Yildiz Sport club amputee athletes.
\end{abstract}

Keywords: Amputee Football, Regular Training, Body Composition

\section{INTRODUCTION}

Disabled individuals can be classified as disability groups such as amputee, cerebral palsy, mental retardation, visual impairment, spinal cord injury, les autres, etc. Ampute is a partial or complete lack of extremity limbs (arm, leg, shoulder, elbow, wrist, hip, knee, ankle joint, etc.) (9).
Physical characteristics are among the factors that influence performance. It is seen in the literature researchs that physical properties affect physiological capacity. The main reason why the athletes can not achieve the desired level of performance in the sports are they do not have body compositions such as weight, the body mass index, 
the percentage of fat etc. When these characteristics appropriate, the athlete may not be able to best perform. At the same time flexibility, speed, strength and durability performance are appropriate, which improves performance of athletes (13).

Amputee football is a variation of conventional football, which is joined by athletes with lower extremity amputation and upper extremity amputation (goalkeeper)(11). Amputee football, consisting 50 minutes in total

\section{METHOD}

The sample of the study consisted of 12 amateur athletes in ages 16-39 (X age: $25.17 \pm 7.03$ years, $X$ height: $1.74 \pm$ 8.07 meters, $X$ weight: $75.09 \pm 15.16$ kg)in Ay Yildiz Sport Club Ampute Football Team. The training program consists of durability, strength, speed, quickness, technique, coordination and flexibility. Body height, body weight, heart rate measurements, skin fold thickness and body mass index (BMI) were measured before and after 8 weeks of regular training to evaluate body composition. A regular training program including stamina, strength, speed, quickness, coordination, technique and flexibility studies was applied for three weeks a week for eight weeks in order to determine some physical characteristics of the athletes forming the sample. The following measurements were performed before and after this training program. It has been analyzed whether the training program being implemented brings a change in the body composition of amateur athletes. that has 2 circuits of 25 minutes each, is played in an area of 60 meters in length and 40 meters in width. Both teams that have goalkeepers and other players (defensive and offensive) play in positions appropriate to their physical characteristics and amputations (15).

Ampute football includes actions that require explosive power such as bouncing, shooting, direction change, high speed sprints, as well as technical actions passing the opponent while controlling the ball (3).

In our study, height $(\mathrm{cm})$ and body weight $(\mathrm{kg})$ were measured to determine the anthropometric characteristics of athletes. FB 721 brand Body Analyzer was used for height measurement. Measurements were made with bare feet and flat ground. When body weight $(\mathrm{kg})$ was measured, the athletes were asked to go barefoot and onto the meter without clothes to weigh on them. The body weight measurement was made with the Seca 727 electronic measuring instrument.

\section{Body Mass Index (BMI)}

Body length $(\mathrm{cm})$ and body weight $(\mathrm{kg})$ measurements were performed to determine the body mass index of the athletes. Body Mass Index (BMI) is a simple weight-to-height ratio sequence commonly used by adults to classify overweight and obesity. It is defined by dividing the kilogram to square of the height $(\mathrm{kg} / \mathrm{m} 2)$. In the results obtained, it is accepted that the values below 18.50 are weak, between 18.50 and 24.99 are normal weight, 25.00 overweight and 30.00 are obese (14).

\section{Anthropometric Measurements}




\section{Body Fat Percentage Measurement}

Body fat percentage was measured and skin fold thickness was measured in 3 different regions (abdominal, thigh, pectoral) in 12 male amateur amputated athletes. A skinfold caliper is used to measure subcutaneous fat thickness. (Holtain Ltd. UK). All measurements were made at the right side of the body, by placing the caliper $1 \mathrm{~cm}$ away from the thumb and index finger. While reading the caliper, the fingers continued to pinch the skin and waited 1-2 seconds before the caliper was read. Each zone measurement was made 2 times, and the test was made again when the difference between the measurements was not within 1-2 cm. The density of the obtained skin fold thickness was calculated by Jackson and Pollock (1978) formula, while body fat percentage was calculated by Siri formula (8).

Jackson \& Pollock Body Density Formula for Men (BD):

BD $($ Men $)=1.10938-(0.0008267 \times$ $\mathrm{ST})+\left(0.0000016 \times \mathrm{ST}^{2}\right)-(0.0002574 \times$ Age)

Siri formula \% Fat $=(4.95 / \mathrm{BD}-$ $4.50) \times 100$

\section{BD: Body Density}

ST: Skinfold Total (abdominal, thigh, pectoral)

\section{Resting Heart Rate}

An electronic blood pressure measuring device was used to measure the resting heart rate of the athletes (Omrom M1 PlusTM). The measurements were made before and after the 8-week training program. Participants were asked to sit in the chair for five minutes while they did not perform any physical activity. The blood pressure cuff was placed on the lower edge antecubital space approximately $2.5 \mathrm{~cm}$ and the data obtained after the measurements were recorded.

\section{Analysis of Data}

The characteristics of the data set used when statistical analysis is done are important because the statistical technique to be used is decided by looking at the characteristics of the data type. In this sense, the statistical test classification is generally divided into two groups; parametric techniques and nonparametric techniques. In order to apply parametric techniques, the data set must be normally distributed and the number of data must be over 30 . Non-parametric techniques should be used in statistical analyzes for data sets that do not provide these assumptions. The total number of observations in this study is 12 . Therefore, the statistical analysis of the data sets was examined using nonparametric methods.

In this study, the Wilcoxon Marked Rank Test was used for the first and last measurement comparisons of the working group.

\section{Wilcoxon Marked Sequence Test}

If there is a comparison between the two groups and the groups to be compared are dependent, the Wilcoxon Marked Rank Test, one of the nonparametric methods, is used in group comparisons (5). The hypothesis of this test which can be used in the 
matched group comparisons (beforeafter) is as follows:

H0: There is no difference between the two co-measures.

$\mathrm{H} 1$ : There is difference between the two co-measures.

The test statistic is as follows:

$\bar{D}$ : The average of the differences between the previous value and the next value of the queued observations.
$S_{\bar{D}}$ : The standard error of the average difference.

The calculated test statistic is compared with the table value at the determined significance level. If the calculated value is greater than the table value, the basic hypothesis is rejected and it is decided that there is a difference between the measurements.

\section{RESULT}

Table 1. Comparison of Participants' First and Last Week Weight Measurements

\begin{tabular}{|c|c|c|c|c|c|c|}
\hline \multirow{2}{*}{ Variable } & \multirow{2}{*}{ Tests } & \multirow{2}{*}{$\mathbf{n}$} & \multirow{2}{*}{ Avarage } & \multirow{2}{*}{$\begin{array}{c}\text { Standart } \\
\text { Error }\end{array}$} & \multicolumn{2}{|c|}{ Wilcoxon Test } \\
\hline & & & & & $\mathbf{Z}$ & $\mathrm{p}$ \\
\hline \multirow{2}{*}{ Weight } & Pre test & 12 & 75.0917 & 15.16404 & \multirow{2}{*}{$-2,708$} & \multirow{2}{*}{,007 } \\
\hline & Post Test & 12 & 74.1583 & 14.67022 & & \\
\hline
\end{tabular}

* Correlation level $p<0.05$

Weight measurements were made before and after training for the athletes. The statistical difference between the first and last measurements was assessed using the Wilcoxon Sign Test. Table 1 shows the results of the test. Because the probability value obtained from this test was less than 0.05 ( $\mathrm{p}=0.007)$, the basic hypothesis that there was no change between the first and last test was rejected, resulting in a statistical difference between the initial and final test values.

Table 2. Comparison of Participants' First and Last Week Resting Heart Rate Measurements

\begin{tabular}{|c|c|c|c|c|c|c|}
\hline \multirow{2}{*}{ Variable } & \multirow{2}{*}{ Tests } & \multirow{2}{*}{$\mathbf{n}$} & \multirow{2}{*}{ Avarage } & \multirow{2}{*}{$\begin{array}{c}\text { Standart } \\
\text { Error }\end{array}$} & \multicolumn{2}{|c|}{ Wilcoxon Test } \\
\hline & & & & & $\mathbf{Z}$ & p \\
\hline \multirow{2}{*}{$\begin{array}{l}\text { Resting Heart } \\
\text { Rate }\end{array}$} & Pre test & 12 & 73,3333 & 15,16404 & \multirow[b]{2}{*}{$-2,754$} & \multirow{2}{*}{,006 } \\
\hline & Post Test & 12 & 69,0000 & 14,67022 & & \\
\hline
\end{tabular}

${ }^{*}$ Correlation level $p<0.05$

Resting Heart Rate measurements were performed before and after training for the athletes. The statistical difference between the first and last measurements was assessed using the Wilcoxon Sign Test. Table 2 shows the results of the test. Because the probability value obtained from this test was less than $0.05(p=0.006)$, the basic hypothesis that there was no change between the first and last test was rejected, resulting in a statistical difference between the initial and final test values. 
Table 3. Comparison of Participants' First and Last Week Body Mass Index Measurements

\begin{tabular}{lcccccc}
\hline \multirow{2}{*}{ Variable } & Tests & n & Avarage & \multirow{2}{*}{$\begin{array}{c}\text { Standart } \\
\text { Error }\end{array}$} & \multicolumn{2}{c}{ Wilcoxon Test } \\
\hline Body Mass & Pre test & 12 & 24,8330 & 5,58319 & & p \\
Index(BMI) & Post Test & 12 & 24,5264 & 5,44264 & & \multirow{2}{*}{008} \\
\hline
\end{tabular}

* Correlation level $p<0.05$

Body mass index (BMI) the probability value obtained from this measurements were made before and test was less than $0.05(p=0.008)$, the after training for the athletes. The basic hypothesis that there was no statistical difference between the first change between the first and last test and last measurements was assessed using the Wilcoxon Sign Test. Table 3 shows the results of the test. Because was rejected, resulting in a statistical difference between the initial and final test values

Table 4. Comparison of Participants' First and Last Week Body Fat Percentage Measurements

\begin{tabular}{|c|c|c|c|c|c|c|}
\hline \multirow{2}{*}{ Variable } & \multirow{2}{*}{ Tests } & \multirow{2}{*}{ n } & \multirow{2}{*}{ Avarage } & \multirow{2}{*}{$\begin{array}{l}\text { Standart } \\
\text { Error }\end{array}$} & \multicolumn{2}{|c|}{ Wilcoxon Test } \\
\hline & & & & & $\mathrm{Z}$ & $p$ \\
\hline \multirow{2}{*}{$\begin{array}{l}\text { Body Fat } \\
\text { Percentage }\end{array}$} & Pre test & 12 & 12,2898 & 5,43634 & \multirow[b]{2}{*}{$-2,293$} & \multirow{2}{*}{ 022 } \\
\hline & Post Test & 12 & 12,0928 & 5,23160 & & \\
\hline
\end{tabular}

${ }^{*}$ Correlation level $p<0.05$

Body fat percentage measurements were made before and after training for the athletes. The statistical difference between the first and last measurements was assessed using the Wilcoxon Sign Test. Table 4 shows the results of the test. Because the

probability value obtained from this test was less than 0.05 ( $p=0.022$ ), the basic hypothesis that there was no change between the first and last test was rejected, resulting in a statistical difference between the initial and final test values.

\section{DISCUSSION \& CONCLUSION}

It is seen in the scientific researches for Amputee football which is a new sport in our country and develops to a great extent in a short time that it can be done whether in the body composition or the sporting successes with a regular work program, such as in other sports. Kayıhan and colleagues (2011) stated that the Turkish Amputee National Team athletes have lower fat percentage and lower body mass index than the athletes in the literature because they might have a better training content and application (10).

Mean values of body mass index of athletes in our study are normal according to World Health Organization classification. There was a significant difference in these values after the eight-week training program $(\mathrm{p}<0.05)$.

Güneş H et al. (1998) reported that their work, blood pressure, and body temperature had an effect on sport performance (4). At the same time, Beam W. and Adams G. (2013) stated that exercising and physical activity for 30 minutes a day is a factor reducing blood pressure (2). In this context, 
participants in our study had a significant difference in the results of first and last test resting heart rate (HR) after an 8-week regular training program $(\mathrm{p}<0.05)$.

Ordoñez F. J. et al. reported that the 12-week exercise program led to a significant change in the body fat percentage of the adolescents with Down's syndrome (12). Likewise, in this study, after 8 weeks of regular training program, a significant difference happened in body fat percentages of amateur amputee athletes $(\mathrm{p}<0.05)$.

Significant findings in the first and last measurement data obtained in this study did not differ according to the positions the players played in the team. Similarly, M.A.M. Simim, et al. (2013) reached the conclusion that the physical performance indicators of Brazilian Amputee National Team players did not differ according to the positions they played in the team (11).

As a result, 12 amateur athletes playing amputee football in Malatya Ay Yildiz Ampute Sports Club showed significant changes before and after eight weeks of regular training in body composition. Thus, the applied training program has been similar to other studies in the literature. It can be said that regular training program applied before this change in the body composition of the 12 amateur amputee athletes is an important factor. Such that Yildiz H, et al. (2015) reported significant differences on the physical parameters of amateur amputee football players before and after the preparation period, which consisted of a 6-week regular training program (16). In addition, Hutzler Y, et al. (1993) assert that regular physical activity for people with disabilities will positively affect their psychological structure as well (6). As a result, it is an effective way to deal with these difficulties for disabled people to do any sport amateur and regular training program because disabled people have difficulty in socializing and accepting themselves in society.

\section{REFERENCES}

1. Aytar, A, Pekyavas NO, Ergun N, \& Karatas, $\mathrm{M}$. Is there a relationship between core stability, balance and strength in amputee soccer players? A pilot study. Prosthetics and Orthotics International, 2012; 36 (3): 332-338.

2. C Beam W, Adams G. Egzersiz Fizyolojisi Laboratuvar El Kitab1 / Exercise Physiology Laboratory Manuel 6. Basımdan Çeviri, 2013; 179-179.

3. Göktepe AS. Energy Systems in Sports. In C. o. E. D. A. Terrorism (Ed.), Amputee Sports for Victims of Terrorism 2007; 24-31 Ankara, Turkey: IOS Press .

4. Güneş H, Arslan A, Erdal S, Toplam Dinlenme nabzının Sirkadien Ritminin Araştırılması, Hacettepe Spor Bilimleri Dergisi 1998; 9 (1): 15-29.

5. Hubert W. On the Kolmogorov-Smirnov Test for Normality with Mean and Variance Unknown, Lilliefors Journal of the American Statistical Association, 1967; 62 (318): 399-402.

6. Hutzler Y, Bar-Eli M. Psychological benefits of sports for disabled people. A review Scand J Med Sci Sports, 1993; 3 (1): 217-228.

7. Invited Review Paper / Çağrılı Derleme Makalesi Kolmogorov-Smirnov, Lilliefors And Shaphiro-Wilk Testsfor Normality Mehmet Genceli 16.10.2007.

8. Jackson AS, Pollock M. Generalized equations for predicting body density of men, British Journal of Nutrition, 1978; 40 (1): 497-502.

9. Kaya NK. Bedensel Engellilerde Sportif Aktiviteler ve Klasifikasyon, Uluslararası 
Katılımlı Engellilerde Beden Eğitimi ve Spor kongresi Konya, 2011: 42-46.

10. Kayihan G, Özkan A, Yiğiter KB, Ergun N, Ersöz G, Dört Haftalik Temel Antrenmanin Ampute Futbol Milli Takiminin Vücut Kompozisyonu Üzerine Etkisi. Selçuk Üniversity Journal of Physical Education and Sport Science, 2011; 13 (Ek Sayı): 140-143.

11. MA. M Simim BV C Silva M. Marocolo Júnior EL. Mendes MT. Mello \& GR. Mota Anthropometric profile and physical performance characteristic of the Brazilian amputee football (soccer) team, Motriz, Rio Claro, 2013; 19 (39): 641-648.

12. Ordoñez FJ, Rosety M, Manuel RosetyRodriguez. Influence of 12-week exercise training on fat mass percentage in adolescents with Down syndrome. Med Sci Monit, 12 (10): 416-419.
13. Özkan A, Arıburun B, Kin İşler A: Ankara'daki Amerikan Futbolu Oyuncularının Bazı Fiziksel ve Somatotip Özelliklerinin İncelenmesi. Gazi Üniversitesi Beden Eğitimi ve Spor Bilimleri Dergisi, 2005; 10 (2): 35-42.

14. WHO. Physical status: the use and interpretation of anthropometry. Report of a WHO Expert Committee. WHO Technical Report Series 854. Geneva: World Health Organization, 1995.

15. Yazıcıŏlu K., Amputee Sports for Victims of Terrorism, IOS Pres, 2007; 1-40.

16. Yıldız, H, Biçer $M$, Akcan F, Mendeş B. Ampute Futbolcularda Hazırlık Dönemi Çalı̧̧malırının Fiziksel Ve Fizyolojik Parametreler Üzerine Etkileri. Spor ve Performans Araştırmaları Dergisi, 2016; 7(1) 45-52. 